\title{
1. International investment law and the global financial architecture: Identifying linkages, mapping interactions
}

\author{
Christian J. Tams, Stephan W. Schill and \\ Rainer Hofmann
}

\section{INTRODUCTION}

Linkages between international investment law and other areas of international law and regulation are frequently explored. Investment law's relationships with human rights, environmental protection and the law of sustainable development have been studied in detail; 1 interactions with other areas of international economic law (such as international trade

1 For a general account see the contributions to Rainer Hofmann and Christian J Tams (eds), Investment Law and Its Others (Nomos 2012). On the relationship of investment law and human rights, see, e.g., Ursula Kriebaum, Eigentumsschutz im Völkerrecht: Eine vergleichende Untersuchung zum internationalen Investitionsrecht sowie zum Menschenrechtsschutz (Duncker \& Humblot 2008); Pierre-Marie Dupuy, Ernst-Ulrich Petersmann and Francesco Francioni (eds), Human Rights in International Investment Law and Arbitration (OUP 2009); Diana Desierto, Public Policy in International Economic Law: The ICESCR in Trade, Finance, and Investment (OUP 2015); Lone Wandahl Mouyal, International Investment Law and the Right to Regulate: A Human Rights Perspective (Routledge 2016). On linkages between investment law and environmental law, see, e.g., Jorge E Viñuales, Foreign Investment and the Environment in International Law (CUP 2012); Pierre-Marie Dupuy and Jorge E Viñuales (eds), Harnessing Foreign Investment to Promote Environmental Protection: Incentives and Safeguards (CUP 2013). The relationship between investment law and development is addressed in Stephan W Schill, Christian J Tams and Rainer Hofmann (eds), International Investment Law and Development; Bridging the Gap (Edward Elgar Publishing 2015). 
disciplines) also attract much attention. ${ }^{2}$ This notwithstanding, scholarship so far remains rather unbalanced as many white spots remain on the academic map. The relationship between international investment law and the relatively fuzzy regime of rules regulating global financial markets is one such white spot. This regime, which is referred to here as the 'global financial architecture', consists of binding and non-binding rules of national, regional, supranational, and international law that are dispersed across different regimes, including European Union (EU) law, world trade law, the international law governing capital controls, banking and financial market regulation. It is influenced by institutions as diverse as the World Trade Organization (WTO), the International Monetary Fund (IMF), or the International Organization of Securities Commissions (IOSCO). The global financial architecture is clearly related to international investment law, but quite how the two regimes affect each other still remains uncertain and insufficiently conceptualized. The contributions to the present book seek to dispel some of that uncertainty and map out linkages.

The book proceeds from the assumption that the interactions between international investment law and the global financial architecture are increasingly important, and that they should be studied in more detail. They are not entirely novel, to be sure. As parts of the international legal infrastructure governing the global market economy, international investment law and the global financial architecture have never been sealed off from one another. The most visible aspect of international investment law - viz. its most relevant procedural arm, the dispute settlement mechanism established under the Convention on the Settlement of Investment Disputes Between States and Nationals of Other States (ICSID Convention $)^{3}$ - was established under the auspices of a leading financial institution, the World Bank, and continues to benefit from this patronage. ${ }^{4}$

2 See, e.g., Rainer Hofmann, Stephan W Schill and Christian J Tams (eds), Preferential Trade and Investment Agreements: From Recalibration to Reintegration (Nomos 2013); Jürgen Kurtz, The WTO and International Investment Law: Converging Systems (CUP 2016). 159.

Adopted 18 March 1965, entered into force 14 October 1966, 575 UNTS

4 See ICSID Convention, fifth preambular paragraph ('Desiring to establish such facilities [for international conciliation or arbitration] under the auspices of the International Bank for Reconstruction and Development'); and further Christoph Schreuer, Loretta Malintoppi, August Reinisch and Anthony Sinclair, The ICSID Convention. A Commentary (2nd edn, OUP 2009) 8 (mentioning ICSID's 'close administrative ties to the World Bank', which 'have proven to be 
Likewise, at least since the Fedax case, ${ }^{5}$ financial instruments of one sort or another, have been objects of investment arbitration, 6 just as tribunals, since investment treaty arbitration's early times, have addressed disputes relating to a government's treatment of banks. ${ }^{7}$

And still, interactions have recently increased, quantitatively as much as qualitatively. They have done so mainly, albeit not exclusively. in the

extremely useful'). For a more cautious account see Julien Fouret, 'The World Bank and ICSID: Family or Incestuous Ties?' (2007) 4 Int'l Org LRev 121.

5 Fedax NV v Republic of Venezuela, ICSID Case No ARB/96/3, Decision of the Tribunal on Objections to Jurisdiction (11 July 1997) paras 20-40.

6 See, e.g., Fireman's Fund Insurance Co $v$ The United Mexican States, ICSID Case No ARB(AF)/02/1, Award (17 July 2006) (debentures); Continental Casualty Company $v$ Argentine Republic, ICSID Case No ARB/03/9, Award (5 September 2008) (certificates of deposit); Abaclat and others $v$ Argentine Republic (formerly Giovanna A Beccara and others $v$ Argentine Republic), ICSID Case No ARB/07/5, Decision on Jurisdiction and Admissibility (4 August 2011) (sovereign bonds). For further examples see Charles $\mathrm{N}$ Brower and Alexandra Goetz-Charlier, 'International Investment Arbitration and the Global Financial System: Are They "Yin" and "Yang" or like Oil and Water?' (in this volume) 23, $27 \mathrm{ff}$.

7 See, e.g., Alex Genin, Eastern Credit Ltd, Inc and AS Baltoil v The Republic of Estonia, ICSID Case No ARB/99/2, Award (25 June 2001); Ceskoslovenska Obchodni Banka, AS v The Slovak Republic, ICSID Case No ARB/97/4, Award (29 December 2004); Saluka Investments BV v The Czech Republic, UNCITRAL, Partial Award (17 March 2006). More recent examples include Valeri Belokon v Kyrgyz Republic, UNCITRAL, Award (24 October 2014) and Hesham T M Al Warraq v Republic of Indonesia, UNCITRAL, Final Award (15 December 2014). Virtually all of these cases concern the observance of host State regulators of general rule of law standards in administering existing domestic financial markets and banking regulation. To our knowledge, there are, by contrast, no cases where investment treaty cases were brought against the very regulation of financial markets or the banking sector. This may be explained by the fact that financial market participants operate in highly regulated markets in the first place, where regulation as such is not considered an interference with the right to property or the freedom of enterprise as long as the regulatory framework is applied in a non-discriminatory manner and administered according to accepted, transparent and fair rules of procedure. For rare exceptions - both dismissed on jurisdictional grounds - where the regulatory approach as such, or rather the alleged lack thereof, was at stake, see Alasdair Ross Anderson et al $v$ Republic of Costa Rica, ICSID Case No ARB(AF)/07/3, Award (19 May 2010) and Ping An Life Insurance Company of China and Other $v$ Belgium, ICSID Case No ARB/12/29, Award (30 April 2015). 
wake of crises: ${ }^{8}$ the early twenty-first century disruptions of financial markets - most prominently the Argentinean debt crisis of 2001, the global financial crisis of 2008, and the ongoing sovereign debt crisis have tested the regulatory architecture of international finance and highlighted its weaknesses. On the institutional level, these crises have prompted calls for strengthened transnational cooperation (culminating in calls for the establishment of an international financial organisation ${ }^{9}$ ) and led to increased powers of monitoring bodies at the international, regional and national levels. The global financial architecture has thickened institutionally as a result. ${ }^{10}$

The global financial architecture has also shown its teeth, at least at times. Recent years have seen governments around the world re-regulate (or consider re-regulating) markets in response to financial, banking, and sovereign debt crises. Re-regulation is most clearly felt in the banking sector, but has also affected capital markets, rating agencies, and crossborder finance. It has in some cases led to intrusive measures, from unilateral debt restructurings, to compulsory bail-ins and (in exceptional cases) the nationalisation of banks. These measures have typically been taken to stabilise financial markets and to reduce the exposure of governments and central banks, but also of supranational and international institutions (such as the IMF, the European Central Bank, or the European Stability Mechanism) as lenders of last resort. Their overarching rationale has been to preserve macroeconomic stability: the

8 The relationship between international investment law and the global financial architecture is not just one of crisis, of course. However, crises and crisis-management measures have thrown interactions and linkages into sharp relief.

9 See for an analysis of debates Rosa M Lastra, 'Do We Need a World Financial Organization?' (2014) 17 JIEL 787.

10 The United Nations Conference on Trade and Development (UNCTAD) provides an overview; see UNCTAD, Trade and Development Report, 2015: Making the International Financial Architecture Work for Development (United Nations 2015) Chapter IV: Financial Regulatory Reform after the Crisis <http:// unctad.org/en/PublicationsLibrary/tdr2015_en.pdf> accessed 4 July 2016. For excellent accounts see Robert B Thompson, 'Financial Regulation's Architecture Within International Economic Law' (2014) 17 JIEL 807; Christian Tietje, 'The International Financial Architecture as a Legal Order' (2011) 54 GYIL 1; Matthias Goldmann, 'International Investment Law and Financial Regulation: Towards a Deliberative Approach ' (in this volume) 57, $67 \mathrm{ff}$. 
'prevention of systemic failure' has emerged as a 'unifying principle' of international financial regulation. ${ }^{11}$

Re-regulation, in turn, has implicated international investment law, which is based on a different rationale. International investment agreements (IIAs) define and delimit rights of investors, which are to be protected from State interference, including potentially interferences pursued in the name of macroeconomic stability. The question is how far these rights reach, and to what extent they constrain the freedom of regulators even during economic crises. This question has so far primarily been addressed by 'arbitral tribunals [which] have been confronted with more and more disputes related to financial disruptions'. ${ }^{12}$ Investment arbitration has become a site of contestation in the struggle pitting crisis responses against investment protection. While these disputes are to be addressed by employing the usual techniques of treaty interpretation and application, the stakes are unusually high: hence dire warnings that by admitting sovereign debt litigation, ICSID tribunals would open 'Pandora's box'13 or enter 'a vast new field, with incalculable economic and political ramifications' (as noted by Arbitrator Abi-Saab in the controversial Abaclat award). ${ }^{14}$ The interactions and linkages between international investment law and the global financial architecture are to be assessed against this background: it is no ordinary relationship, but one of high drama.

Assessing the relationship between international investment law and the global financial architecture is not a straightforward task, as there is no overarching, guiding principle that clarifies how the two fields relate to each other, and how their different rationales are to be reconciled (if at all). No master plan defines their interaction. Similarly, no obvious forum or coordinating institution exists in which answers to questions of

11 See R Michael Gadbaw, 'The Prevention of Systemic Failure as a Unifying Principle of International Economic Law' (2014) 17 JIEL 823: 'The financial crisis and its lingering aftermath have focused international economic law on systemic failure.'

12 Brower and Goetz-Charlier (n 6) 29. See ibid., 23: 'it is now widely accepted that claims made in investment arbitration proceedings may affect the global financial system'.

13 Michael Waibel, 'Opening Pandora's Box: Sovereign Bonds in International Arbitration' (2007) 101 AJIL 711.

14 Dissenting Opinion of Arbitrator Abi-Saab, in Abaclat and Others $v$ Argentina, ICSID Case No ARB/07/5, Decision on Jurisdiction and Admissibility (8 October 2011) para. 35. 
integration or separation could be debated authoritatively. ${ }^{15}$ There is no equivalent in international financial law to, say, the (admittedly shortlived) Singapore/Doha discussion about bringing investment disciplines under the umbrella of WTO law. ${ }^{16}$ The WTO and its provisions on financial services in the General Agreement on Trade in Services ${ }^{17}$ provide a multilateral framework of sorts, but it is not properly integrated with the investment treaty regime and covers only one aspect of global financial market regulation. The same holds true for the IMF, IOSCO, the

15 The dearth of multilateral fora is a widely acknowledged feature of international investment law. In the words of Joost Pauwelyn, 'Rational Design or Accidental Evolution? The Emergence of International Investment Law' in Zachary Douglas, Joost Pauwelyn and Jorge Viñuales (eds), The Foundations of International Investment Law: Bringing Theory into Practice (OUP 2014) 11, 14 investment law

unlike, for example, UN, WTO or EU law ... is not organized around a multilateral treaty or central international organization. Instead, [it] is heavily decentralized and composed of a multitude of bilateral, regional and multilateral treaties (BITs, NAFTA, FTAs, the ECT etc.), customary international law, domestic laws, contracts and insurance schemes, and a diversity of arbitral institutions (ICSID, UNCITRAL, PCA, ICC, SCC etc.) and domestic courts and investment agencies, without central authority.

As regards financial regulation, the situation is not much different. As Thompson (n 10) 822 observes: 'there is no treaty at its core and there are no hard law rules such as the WTO's dispute resolution system'.

16 The WTO first Ministerial Meeting in Singapore 1996 decided to establish a working group to assess the relationship between trade and investment; the 2001 Doha Ministerial Declaration expressly '[r]ecogniz[ed] the case for a multilateral framework to secure transparent, stable and predictable conditions for long-term cross-border investment, particularly foreign direct investment' (Doha Ministerial Declaration, WTO Doc. WT/MIN(01)/DEC/1, 20 November $2001<$ https://www.wto.org/english/thewto_e/minist_e/min01_e/mindecl_e.htm> accessed 15 June 2016). However, as Andreas Ziegler notes, this attempt at conscious regime expansion was soon given up:

'Trade and Investment' became one of the so-called Singapore issues that were envisaged for future negotiations within the WTO. As a matter of fact, when the next round of trade negotiations of the WTO was launched in 2001 in Doha (Qatar) this area still figured prominently in the mandate given by Ministers. However, as early as 1 August 2004, this topic was dropped officially ... during the consultations among members in Geneva.

See Andreas Ziegler, 'Preferential Trade and Investment Agreements (PTIAs) and the Bilateralism/Multilateralism Divide' in Hofmann, Schill and Tams (n 2) 189, 208.

Adopted 15 April 1994, 1869 UNTS 183, Annex on Financial Services. 
Organisation for Economic Co-Operation and Development (OECD), or other inter-governmental organisations or platforms.

In the absence of an obvious forum or coordinating institution, linkages between investment law and the global financial architecture have so far mainly been explored in arbitral proceedings, at a granular level, in a process of claim and contestation opposing investors and respondent States in the framework of a particular dispute, rather than by conscious regime design. And while some of the more recent IIAs notably comprehensive free trade agreements (FTAs) - now contain separate chapters on financial services, ${ }^{18}$ their detailed rules cannot lightly be read into the majority of older treaties. For the most part, linkages and interactions between international investment law and the global financial architecture are therefore being worked out in the practice of investment dispute settlement and in treaty drafting.

All this is only natural. Both investment law and global financial law have emerged in functionally separate spheres. Each has followed its own ('sector specific'19) logic, rather than an overarching, integrated regulatory agenda for international economic relations. And of course, neither field is static; both keep evolving. The dynamic development of investment law is widely appreciated:20 it has primarily been achieved through a process of 'normative outreach', as a limited set of treaty standards has come to be applied to an increasingly wide range of host State measures, at the instigation of an increasing range of eligible claimant investors. Seen in this light, financial regulation is just one further area of host State activity that (perhaps to the surprise of host States) is being brought before arbitral tribunals, which scrutinise it from an investment law perspective.

Global financial law's trajectory has perhaps not been as clear. Different aspects - monetary policy, banking regulation, fiscal policy,

18 For recent examples see, e.g., Chapter 11 of the Trans-Pacific Partnership (TPP) (5 October 2015) <https://ustr.gov/trade-agreements/free-trade-agreements/ trans-pacific-partnership/tpp-full-text> accessed 30 June 2016 and Chapter 15 of the Canada-EU Comprehensive Economic and Trade Agreement (CETA) (29 February 2016) <http://trade.ec.europa.eu/doclib/docs/2016/february/tradoc_ 154329.pdf $>$ accessed 30 June 2016.

19 Goldmann (n 10) 62.

20 See, e.g., Stephan W Schill, 'W(h)ither Fragmentation? On the Literature and Sociology of International Investment Law' (2011) 22 EJIL 875: an 'unprecedented increase in practical importance of this area of international law and dispute settlement'. 
etc. - have been addressed separately, in different fora and by different actors. As has been observed perceptively, the structure of the international financial regime 'has something of an ad hoc character'. ${ }^{21}$ It certainly is more 'bric-à-brac' than 'coherent system'.22 This notwithstanding, the global financial architecture as a whole has gained contours following the recent crises, and visibility. No wonder it should attract attention, including from international investment law. And given the absence of specific judicial or arbitral dispute settlement mechanisms in the international financial regime, it is perhaps no wonder either that controversies about the more intrusive financial measures are brought before investment tribunals. With this increasing interaction at the dispute settlement front, treaty makers, in turn, feel the need to define the position of investment agreements vis-à-vis financial regulation with greater precision, resulting in manifold and complex linkages and interactions.

\section{A RICH AND COMPLEX RELATIONSHIP}

The contributions in this book illustrate the rich and complex relationship between international investment law and the global financial architecture. In line with the broader developments sketched out in the preceding paragraphs, they do so mainly from the perspective of international investment law, inquiring how financial regulation, financial marketrelated conduct of States in various forms, and considerations that have purchase in the financial field more generally, could influence the making, interpretation and application of IIAs. The potential for such influence is certainly there; this is not a one-way street. And while contributors adopt different, at times competing, approaches, the subsequent chapters illustrate the diversity of linkages that exist between international investment law and the global financial architecture.

Readers will find, in the detailed analyses that follow, considerations concerning the scope of investment protection rules (which may or may not cover financial instruments, and different types of creditors), as well as an in-depth engagement with particular regulatory measures (bail-ins, sovereign defaults, etc.), which may or may not fall foul of investment treaty standards (e.g., the protection against uncompensated expropriation, against unfair and inequitable treatment, and against restrictions on

21 Thompson (n 10) 813.

22 Cf. Jean Combacau, 'Le droit international: Bric-à-brac ou système' (1986) 31 Archives de Philosophie du Droit 85. 
capital transfer). And as many regulatory measures are adopted under exceptional circumstances, and often with the prompting of international actors, there is ample consideration of justifications and excuses that could legitimise interference with investor protection (necessity, force majeure, contributory fault, etc.) and of the proper addressee of claims.

More specifically, the subsequent chapters are grouped in four parts, based on the type of linkage that is being addressed and the form of engagement with the relationship between international investment law and the global financial architecture.

\section{A. Overarching Perspectives}

The two chapters by Charles N. Brower and Alexandra Goetz-Charlier and by Matthias Goldmann, together with this Introduction, comprise the 'General Part' of the inquiry. They contain overarching perspectives on the relationship between international investment law and international financial law. Mapping out diverse linkages between investment law and the global financial architecture, Brower and Goetz-Charlier query whether the relationship resembles that of oil and water - which are 'immiscible' and 'should be kept apart' - or 'yin and yang' - i.e., 'complement[ing] each other to form a consistent and virtuous whole'. ${ }^{23}$ Reviewing recent case-law and treaty-making practice, they find evidence of both: while 'arbitration ... has proved its complementing role for the global financial system over the course of major financial disruptions,' States increasingly seem intent to 'shield prudential regulation in the financial sector from investment claims.' 24

Faced with these diverging trends, Matthias Goldmann robustly argues for an approach that sees investment law as part of a broader (and presumably 'virtuous') whole. In his assessment, the 2008 global financial crisis, for all its problems, has raised awareness for the 'systemic interrelations among the various segments of economic policy', 25 that is, monetary and fiscal policy, banking regulation, development finance and investment law. In his view, "narrow regulatory responses in line with the theory of functional separation' 26 (between different sectors of economic governance) are insufficient (and their insufficiency is increasingly recognised).

\footnotetext{
23 Brower and Goetz-Charlier (n 6) 27.

24 Ibid., 53 and 46.

25 Goldmann (n 10) 67.

26 Ibid., 65.
} 
Goldmann's reform proposals are two-fold: institutional and interpretative. '[I]nstitutional design needs to allow for a coherent, concerted response'; 27 yet despite some movement, this remains difficult to implement, especially on the international plane. In the meantime, a 'deliberative approach' focusing on the interpretation and application of the existing law could facilitate solutions that, in Brower's and GoetzCharlier's terminology might qualify as 'yin and yang', i.e., result in a consistent and virtuous whole. For Goldmann, such a deliberative approach requires openness towards 'different rationalities of various segments of financial regulation'. ${ }^{28}$ Investment tribunals more specifically would be required to look beyond the immediate investment treaty context and 'accommodate other perspectives', 29 including by giving some weight to broader macroeconomic goals of financial stability and organised debt restructuring. All this, as Goldmann argues, can be achieved by relying on interpretative devices such as the principle of 'systemic integration' laid down in Article 31(3)(c) of the Vienna Convention on the Law of Treaties (VCLT) and by reliance on supplementary means of treaty interpretation (Article 32 VCLT) ${ }^{30}$

But where does (desirable) deliberative openness turn into the (undesirable) watering down of investment treaty standards; at what point does the accommodation of a competing rationality result in a sell-out of investment law's own rationality? The remaining ten contributions can be seen as reflections on how the line - between accommodation and sell-out - has been, or should be, drawn. They are grouped into three further parts, which reflect the most prominent sites of the interaction between investment law and financial regulation.

\section{B. Sovereign Debt Restructurings}

Sovereign debt restructuring, which is the focus of contributions in Part II of the book, is one of these sites. Insistence on investment protection here seems to meet with firm opposition. Individual hold-out creditors, so a prominent argument runs, ought not to be able to undermine legitimate restructuring initiatives; investor rights would have to yield to 'the

\footnotetext{
27 Ibid., 68.

28 Ibid., 69.

29 Ibid., 84.

30 Adopted 23 May 1969, entered into force 27 January 1980, 1155 UNTS 331.
} 
international public interest in financial stability'. ${ }^{31}$ In line with this popular view, and despite considerable opposition, UN organs and agencies are pushing a legislative agenda designed to result in the clarification of 'Basic Principles on Sovereign Debt Restructuring Processes', which emphasises the right of States to restructure sovereign debt and the principle of '[m]ajority restructuring [which] implies that ... agreements approved by a qualified majority of creditors ... are not to be affected, jeopardized or otherwise impeded by ... a minority of creditors who must respect the decisions adopted by the majority of the creditors' ${ }^{32}$ Four contributions address the complex legal questions raised by sovereign debt restructuring; together they make up the second part of the present volume.

The first of these, by Hayk Kupelyants, approaches the topic from the perspective of the police powers doctrine, inquiring whether reliance on that doctrine could serve to shield debt restructuring from investment treaty claims. Drawing in a comparative law perspective on national case law in order to concretise the meaning of vague investment treaty standards, ${ }^{33}$ Kupelyants sees only a limited role for the police powers doctrine in relation to sovereign (or 'public', as opposed to private-toprivate) debt. In his assessment, national jurisprudence from the United States, Russia and England suggests that 'sovereign debts are subject to the common regime of private contracts; and ... the State cannot rely on the police powers doctrine to alter the obligations it has entered into in a unilateral manner' ${ }^{34}$ Only 'in exceptional circumstances, [would] States - facing a genuine financial crisis and ensuring an adequate protection for bondholders $-\ldots$ be able to engage in more or less innocuous modifications of domestic-law bonds' ${ }^{35}$ Where States seek to do more

31 See Christoph Ohler, 'Restructuring Sovereign Debt on the Basis of Collective Action Clauses' (in this volume) 120, 122. For more on the need to ensure orderly restructuring see, e.g., the considerations in UNCTAD, Sovereign Debt Restructuring and International Investment Agreements (IIA Issues Note 2/2011) <http://unctad.org/en/Docs/webdiaepcb2011d3_en.pdf> accessed 30 June 2016.

32 United Nations General Assembly (UNGA) Res 319 (10 September 2015), 'Basic Principles on Sovereign Debt Restructuring Processes', UN Doc No A/RES/69/319, paras 1 and 9.

33 For a detailed assessment of the role of comparative law in the interpretation of investment treaty standards see the contributions in Stephan W Schill (ed.), International Investment Law and Comparative Public Law (OUP 2010).

34 Hayk Kupelyants, 'Police Powers of the State in Sovereign Debt Restructurings' (in this volume) 89, 111.

35 Ibid., 118-119. 
than that, they need to look beyond the police powers doctrine. There is, for Kupelyants, therefore only limited room to derogate from investment law by unilateral 'police power' action.

In their respective contributions, Christoph Ohler, Yanying $L i$ and Marie Sudreau explore the legal principles governing sovereign debt restructurings not based on police powers. Noting the absence of a coherent 'international practice on sovereign insolvencies,' Ohler inquires to what extent collective action clauses (CACs), which allow qualified majorities of creditors to agree to a restructuring that is legally binding on all creditors, could facilitate the search for solutions to sovereign debt crises. In his view, CACs 'promise to offer viable solutions for a complex and burdensome economic situation' ${ }^{36}$ If preceded by bona fide negotiations between the State and its creditors, which in turn have been conducted in an inclusive and transparent manner, Ohler argues, 'there is no room to assume that a debt restructuring violates international investment law'. ${ }^{37}$ In Ohler's view, problems of sovereign debt restructuring would thus be addressed preferably through contractual arrangements. This would indeed seem to be an elegant way of avoiding outright clashes between investment protection and the need to ensure orderly debt restructuring.

Yanying Li's chapter continues the discussion of CACs. It contains a detailed analysis of the different types of clauses (notably the single-limb procedure enabling the modification of contract terms on the basis of a single vote across all affected instruments) and the conditions of their operation. Single-limb voting clauses are particularly intrusive from the perspective of minority bondholders and come closest to bankruptcy proceedings for States. To gauge their interactions with international investment law, it thus seems useful to draw an analogy with national bankruptcy laws. According to $L i$, while international jurisprudence on CACs is still in its early stages, national experience with cram-down procedure in domestic bankruptcy law, such as the one found in the United States, could offer guidance, especially in concretising the requirement to treat all creditors in a non-discriminatory manner. By contrast, domestic analogies are unlikely to provide much specific guidance on the level of recovery: while it should 'put in place a mechanism that ensures procedural fairness,' the international community

\footnotetext{
36 Ohler (n 31) 134.

37 Ibid.
} 
would need to 'leav[e] it to the parties to a restructuring to agree on the appropriate amount of debt relief' ${ }^{38}$

Marie Sudreau's contribution completes the analysis of sovereign debt restructurings. Unlike Ohler and $\mathrm{Li}$, she looks not to contractual arrangements, but assesses attempts at clarifying the proper interpretation of treaty and customary law rules. More specifically, Sudreau's focus is on the most prominent recent normative proposal, namely the 2012 Principles on Responsible Sovereign Lending and Borrowing, elaborated within the framework of the United Nations Conference on Trade and Development (UNCTAD). Intended as a general code balancing creditor and State interests (and operationalised through emphasis on transparency, due diligence, and proportionality), these 15 Principles are formally non-binding - but according to Sudreau could help overcome the (at times fractious) debates of the present. For this to be the case, the UNCTAD Principles would need to be taken into account in the interpretation and application of IIAs. This in turn would require some openness towards considerations that are external to investor protection, but could be part of a "more comprehensive integration of public international law into the interpretation of BITs [i.e. bilateral investment treaties]'.39

Just like reliance on CACs addressed by Ohler and $L i$, so too, recourse to the UNCTAD Principles is no panacea, and certainly no substitute for the establishment of an 'institutional structure ... capable of coordinating the interests and functions of international actors (creditor committees, IMF, Paris Club, etc.)' during debt restructurings. However, openness towards the UNCTAD Principles, according to Sudreau, could make investment dispute resolution better equipped to address sovereign lending and borrowing issues. ${ }^{40}$ The recipe she prescribes comes perhaps closest to the 'deliberative approach' outlined by Goldmann, as investment law would be construed in a manner that is open to a 'different rationalit[y]', ${ }^{41}$ namely that of accepting the need for financial stability of indebted States.

38 Yanying Li, 'Sovereign Bond Disputes Before Investment Treaty Tribunals: Safeguarding the Exercise of Collective Action Clauses with a Single-Limb Voting Mechanism' (in this volume) 135, 159.

39 Marie Sudreau, 'Bilateral Investment Treaties and the Principles on Responsible Sovereign Lending and Borrowing: Working Together Towards the Provision of an International Legal Framework Addressing Sovereign Debt Issues?' (in this volume) 160, 189.

40 Ibid., 189-190.

41 See Goldmann (n 10) 69. 


\section{Bank Rescue Measures}

While sovereign debt litigation has a long history, investment arbitration over bank rescue measures, the focus of Part III, is of more recent vintage. Alongside the (partial) nationalisations of financial institutions (such as Northern Rock and Fortis), ${ }^{42}$ 'bail-ins' have risen to prominence in the wake of the 2013 Cyprus banking crisis, which was addressed (among other things) through the compulsory conversion of depositor claims into equity. While permitting for the recapitalisation of failing banks without the use of public money, bail-ins were adopted against the wishes of creditors and/or depositors - who, perhaps predictably, have begun to seek recourse before national and international courts and tribunals. ${ }^{43}$ As with respect to sovereign debt litigation, these proceedings pit investment protection against measures designed to ensure macroeconomic stability and ask how a balance between the two competing interests can be struck. The three contributions comprising the third part of the present volume engage with this question, each offering a detailed analysis of the legal issues raised by on-going disputes on bank rescue measures.

Maurice Mendelson and Martins Paparinskis identify the main issues facing investors who seek to rely on BITs to challenge bank rescue measures. Their analysis highlights the uncertain state of the law, which is only beginning to appreciate the legality of bail-ins. As regards the merits of claims, the expropriation standard is of particular relevance. Are bail-ins expropriatory in nature, and if so, would a putative expropriation be lawful or unlawful? Mendelson and Paparinskis highlight how these standards have been shaped in recent investment jurisprudence and emphasise the importance of 'non-arbitrariness and due process' in the implementation of rescue measures. ${ }^{44}$ They also comment on threshold questions of jurisdiction and admissibility, among them the impact of external pressure on States like Cyprus ('apparently nudged in the direction of applying bail-ins to a broad category of depositors by the so-called Troika') 45 and the scope of coverage of BITs (which may or

\footnotetext{
42 With respect to the latter, see Ping An v Belgium (n 7).

43 See notably the award in Poštová banka, as and Istrokapital SE v The Hellenic Republic, ICSID Case No ARB/13/8, Award (9 April 2015) and the judgment of the Supreme Court of Cyprus, Christodoulou and others $v$ Central Bank of Cyprus and others, Case 551/2013, 7 June 2013.

44 Maurice Mendelson and Martins Paparinskis, 'Bail-Ins and International Investment Law: In and Beyond Cyprus' (in this volume) 193, 206.

45 Ibid., 200.
} 
may not cover deposits). Still, notwithstanding remaining uncertainties, the authors are clear that investment protection law ... has to be ... accounted for as an important element in the complex web of legal rules and procedures framing the responses by States to financial crises ... and will form an important part of the background to any resolution'. ${ }^{46}$ Put simplistically, one might perhaps say that macroeconomic considerations matter, but do not eclipse investment protection.

Anna De Luca proceeds from the same assumption (viz. that international investment law is relevant), but is perhaps more cautious about the potential for investors to obtain damages awards. Her analysis centres on a particular problem faced by depositors and shareholders affected by bank rescue measures, namely issues of causation. Under general international law, claimants are required to establish that the impugned measure (such as a bail-in) was the proximate cause of economic loss. De Luca's analysis of earlier case law on causation suggests that, where claimants have already been in dire financial straits, or even nearinsolvent, damages are typically not awarded because the government intervention did not leave them worse off. As De Luca summarises, 'tribunals have accorded great weight to the imprudent conduct of investors and the critical financial situation of an investment ... these factors were sufficient to break the chain of causation, even where the host State's conduct had been found to be deficient'. ${ }^{47}$ As a consequence, 'it may be difficult for shareholders of a rescued bank to establish a sufficient causal link between the rescue measures and the losses suffered ... [if] the bank was insolvent or in a precarious financial situation before the measures were enacted' ${ }^{48}$

Phoebus Athanassiou is also cautious, but his caution, expressed in the final contribution on bail-ins, is of a different nature. He warns that not too much emphasis should be placed on investment law, which is but 'one piece of the puzzle' of bank rescue measures, and typically is overshadowed by considerations of human rights and equal treatment. This premise leads him to challenge views set out in the two earlier contributions. While problems of causation (as addressed by De Luca) no doubt exist, the real problems facing investor claims, according to Athanassiou, concern the scope of substantive rights: 'the probative demands that human rights law and the [no creditor worse off] principle place on applicants are so high that ... the probability of success of the

\footnotetext{
46 Ibid., 210.

47 Anna De Luca, 'Bank Rescue Measures Under International Investment

Law: What Role for the Principle of Causation?' (in this volume) 211, 236.

48 Ibid.
} 
legal challenge brought against them would appear remote' ${ }^{49}$ As regards the threshold issues (addressed by Mendelson and Paparinskis), Athanassiou is not convinced that bank deposits qualify as investment and thus are protected under BITs. In his assessment, '[m]uch will ... depend on the type of deposits at stake (an overnight deposit is unlikely to qualify as an investment, and the same is probably true of a deposit that is remunerated at a negative rate; conversely, a high-yielding deposit or a fixed-term deposit are closer to an investment) and on their amount' ${ }^{50} \mathrm{In}$ his view, then, investment law - if properly interpreted - presents no real obstacle to bank rescue measures undertaken to ensure macroeconomic stability: it can be (and should be) construed so as to accommodate the broader interest in macroeconomic stability. And so, taken together, the three contributions by Mendelson and Paparinskis, by De Luca and by Athanassiou highlight the complex legal issues raised by bank rescue measures, and at the same time reflect competing visions of the role of investment law in the search for equitable solutions.

\section{Alternative Claims and Defences, New Actors}

Disputes relating to sovereign debt and bank rescue measures have thrown the relationship between international investment law and financial regulation into stark relief. They are not the only sites of the interaction between the two fields though. The three contributions comprising Part IV explore other linkages at which the different rationales of investment protection and financial regulation clash.

Prabhash Ranjan's contribution focuses on monetary transfer provisions of IIAs, which seek to restrict host State interference with capital flows. Though not a new element of treaties, monetary transfer provisions are often treated en passant and have prompted relatively little jurisprudence so far. However, as noted by Kern, 'it can ... be expected that in the years to come, these clauses will be increasingly put to the test'. ${ }^{51}$ Ranjan's contribution identifies the main categories of transfer clauses and assesses their relationship with the Articles of Agreement of the International Monetary Fund (IMF Articles), ${ }^{52}$ which do not per se

49 Phoebus Athanassiou, 'BITs and Pieces: Reflections on the Relevance of BITs in Resolution-Related Litigation' (in this volume) 240, 253.

50 Ibid., 248-249 (emphasis in the original).

51 Carsten Kern, 'Transfer of Funds' in Marc Bungenberg, Jörn Griebel, Stephan Hobe and August Reinisch (eds), International Investment Law. A Handbook (Beck/Hart/Nomos 2015) 870, 886.

52 Adopted 2 July 1944, entered into force 27 December 1945, 2 UNTS 39. 
preclude restrictions on capital account transactions. ${ }^{53}$ As Ranjan notes, straightforward transfer provisions that do not refer to the IMF Articles should be taken at face value - which means they impose real restraints, including during financial emergencies; they should not simply be 'construed away' by reference to some competing interest in financial stability. As a consequence, host States willing to impose capital flow restrictions would be required to rely on non-precluded-measures (NPM) clauses or the necessity defence. As both of these defences do not offer much room for financial manoeuvring, Ranjan suggests a move to more carefully drafted transfer clauses, which 'expressly preserve the host country's rights under the IMF Articles.' 54 Treaty drafters can thus help avoid conflicts for the future by limiting the scope of investment protection available during times of disruption. But where they have not done so, Ranjan suggests that investment protection does not yield, even during financial crises.

Whereas Ranjan addresses an often-overlooked treatment standard, Anastasios Gourgourinis sheds light on a widely ignored defence potentially available to States when intervening in financial markets to react to macroeconomic risks. Drawing on a detailed examination of litigation concerning Iceland's bank rescue measures before the European Free Trade Association (EFTA) Court, ${ }^{55}$ Gourgourinis inquires whether States could rely on force majeure to justify a temporary payment default. In his view, there is certainly room for a plausible argument: 'Iceland's assertion in the Icesave case - that the 2008 global financial crisis and the wholesale collapse of its banking system qualified as force majeure would appear, at least prima facie, tenable.'56 Just as other defences, force majeure is no panacea. ${ }^{57}$ However, given 'the rather limited success' 58 of attempts by States relying on necessity and/or NPM clauses, reliance on it may present an attractive alternative argument, one that

53 See notably Art. VI.3 of the IMF Articles, which accepts that member countries may impose controls if necessary to regulate international capital movement. For comment see Prabhash Ranjan, 'Capital-Flow Management Measures and International Investment Law: Never the Twain Shall Meet?' (in this volume) $257,264-265$.

54 Ibid., 279.

55 See Case E-16/11, EFTA Surveillance Authority v Iceland (Icesave) [2013] EFTA Ct Rep 4.

56 Anastasios Gourgourinis, 'Financial Crisis as Force Majeure Under International Law and EU Law: Defending Emergency Measures, à l'Européenne, in Investment Arbitration Under Intra-EU BITs' (in this volume) 281, 304.

57 Ibid., 315.

58 Ibid., 289. 
suggests that States seeking to preserve macroeconomic stability during times of crisis are entitled to derogate, at least temporarily, from treaty standards established for the benefit of foreign investors.

In the final contribution to the volume, Michael Wolfgang Müller 'steps back' from the debates on particular claims and defences to assess the position of international financial institutions within international investment law and arbitration. In so doing, he picks up themes touched upon by many other contributors, among them Mendelson and Paparinskis (who address the possibility of suing States over measures adopted under international pressure) and Goldmann (who highlights the turn to more robust institutional supervision following the 2008 financial crisis). Müller of course accepts that '[t]he current legal framework of investment protection is based on investor-State relations.' ${ }^{59}$ However, the conduct of international institutions can affect the legal regime governing investor-State relations in manifold ways, notably through the application of rules on attribution, through 'without prejudice'-clauses demarcating the proper scope of investment protection vis-à-vis decision-making within international organisations, and as a consideration guiding the interpretation of investment standards. While conduct of international institutions will hardly ever "exonerate States from international liability tout court', it may help distinguish between justified and illegal forms of interference with investor rights and suggest when investment protection has to give way to a broader interest in macroeconomic stability.

\section{OUTLOOK: BALANCING INVESTMENT PROTECTION AND MACROECONOMIC STABILITY}

This brief summary highlights the manifold linkages - some convergent, some conflictual - between international investment law and the global financial architecture and points towards modalities of co-existence. There are, in the terminology used by Brower and Goetz-Charlier, aspects of 'yin and yang' as well as examples of 'oil and water'. And there are, too, instances in which it may be too early to tell which understanding wins the day, viz. whether investment law should be 'kept

59 Wolfgang Michael Müller, 'International Financial Institutions in Investment Law and Arbitration' (in this volume) 316, 346. 
apart' from the regulation of global financial markets or whether the two could 'complemen[t] each other to form a consistent and virtuous whole' ${ }^{60}$

Notwithstanding these caveats, one trend that does seem to emerge from the more recent interactions is that investment lawyers are aware perhaps increasingly aware - of the risks of interfering all too lightly with regulatory decisions taken by States in respect of financial markets, including sovereign debt restructurings, especially where these have the backing of one or several multilateral institutions, such as the IMF or the EU. Judging from the discussion in many of the contributions to this volume, international investment law is a factor that affects the global financial architecture. But it can be interpreted and applied in a manner that is mindful of the need for financial stability; broader macroeconomic considerations can typically be advanced in investment arbitrations, whether as part of the construction of treaty standards or under clauses containing defences. In fact, at times investment lawyers might be tempted to avoid any scrutiny. In arbitral awards, such as Ping $A n^{61}$ or Poštová banka, ${ }^{62}$ tribunals dismissed claims for lack of jurisdiction; perhaps this outcome (while justified on different grounds) was in fact quite convenient as it meant arbitrators would not need to scrutinise decisions taken during times of financial crises? Whatever one makes of those specific decisions and their reasoning, some arbitral restraint may indeed be warranted, not only because of the systemic implications that the decision about a single dispute could have on global financial markets, but also in light of the limited expertise of investment arbitrators, like that of any domestic court, in questions of macroeconomic regulation. Recent arbitral practice, while not uniform, seems to reflect this.

When looking beyond individual disputes, a similar trend characterises the more recent practice of law-making. As noted above, treaty drafters (e.g., when including special 'financial services' chapters in FTAs or negotiating monetary transfer provisions) seem gradually to accept the need for more detailed provisions that deal with the interaction between international investment law and competing areas of financial market regulation and, at least to some extent, exempt the latter from scrutiny by investment treaty tribunals. Relevant developments in treaty-making include, inter alia, provisions that are sensitive to the need for prudential financial regulation or provisions limiting investment treaty claims arising in the context of sovereign debt restructurings. Similarly, while

\footnotetext{
60 Cf. Brower and Goetz-Charlier (n 6) 27.

61 Ping An v Belgium (n 7).

62 Poštová banka v Greece (n 43).
} 
developments are at an early stage, current debates about sovereign debt restructuring also emphasise respect for a State's right to 'design its macroeconomic policy, including [by] restructuring its sovereign debt' ${ }^{63}$ Just as arbitral practice, so too the recent instances of law-making seem to recognise that international investment law needs to accommodate broader macroeconomic concerns.

Do these trends suggest that international investment law and financial regulation are like 'oil and water'? Probably not, or at least: only rarely. Both fields do interact, after all, and they share basic assumptions, most importantly that global markets will only work efficiently if market participants enjoy freedom from undue government interference, while also benefiting from effective regulation that ensures the functioning of such markets. Instead, what we are witnessing - and what the contributions to the present volume illustrate - is a debate about the proper balance to be struck between the competing interests of regulating global financial markets and ensuring investment protection, or between the 'yin' and the 'yang'. In this debate, much depends on how law-makers, adjudicators, and different market participants view the relationship between international investment law and financial market regulation. As just noted, arbitrators and treaty drafters seem prepared in principle to accept market regulation during times of crisis. But at the same time, they condition such acceptance by emphasising the need for good faith conduct of regulators, transparent regulation and non-discrimination of market participants, and by underlining a preference for multilateral solutions for the regulation of global financial markets.

Just quite how the balance should be struck is open to debate, and given the fragmentation of international investment law and the global financial architecture, this debate really is in the form of a series of discussions that take place in different fora and between different stakeholders. These discussions will need to be informed by a level of open-mindedness and awareness for the logic of the 'other' field, that is, in short, by a 'deliberative approach' in Matthias Goldmann's phrase. The contributions to the volume - so the editors would hope - are examples of such a deliberative engagement. They highlight its promise and its limits and set the stage for further refinement and fine-tuning as the interlinkages between international investment law and the global financial architecture become more sophisticated.

63 GA Res 69/319 (n 32) para. 1. 